\title{
AN ESTIMATING THE EFFECT OF PROCESS PARAMETERS ON METAL REMOVAL RATE AND SURFACE ROUGHNESS IN WEDM OF COMPOSITE AL6063/SIC/AL $\mathrm{A}_{2} \mathrm{O}_{3}$ BY TAGUCHI METHOD
}

\author{
HIMANSHU Prasad Raturi ${ }^{1}$, LALTA Prasad ${ }^{1}$, MAYANK Pokhriyal ${ }^{1}$, VINEET Tirth ${ }^{2}$ \\ ${ }^{I}$ Department of Mechanical Engineering, G.B. Pant Institute of Engineering and Technology, \\ Pauri Garhwal (Uttarakhand)-246194, India, \\ email: himashuraturi3@gmail.com, laltagbpec@gmail.com, mayankgbpec@gmail.com \\ ${ }^{2}$ Department of Mechanical Engineering, College of Engineering, King Khalid University, \\ Abha, Saudi Arabia,email: vtirth@kku.edu.sa
}

\begin{abstract}
The present study was focused on the fabrication of metal matrix and hybrid metal matrix composites through stir casting process. The Aluminium 6063 was used as base material and $\mathrm{SiC} / \mathrm{Al}_{2} \mathrm{O}_{3}$ were used as reinforcement with varying weight $\%$. The parametric study on a wire-cut electro discharge machine was carried out by using Taguchi Method. A statistical analysis of variance (ANOVA) was performed to identify the process parameters that were statistically significant. It was observed that the MRR decreases with increase in the percentage weight fraction of $\mathrm{SiC}$ and $\mathrm{Al}_{2} \mathrm{O}_{3}$ particles in the MMCs and HMMCs. Whereas, the surface roughness parameter increases with increase in the percentage weight fraction of $\mathrm{SiC}$ and $\mathrm{Al}_{2} \mathrm{O}_{3}$ particles due to the hardness of MMCs and HMMCs composites.
\end{abstract}

KEYWORDS: Taguchi, MRR, Surface roughness, Hybrid metal matrix composites, ANOVA

\section{Introduction}

It has been reported in the open literature that metal matrix composite (MMC) and hybrid metal matrix composite (HMMC) are very good alternative to the other conventional materials. The thermo-physical properties as well as other properties of MMCs and HMMCs support their uses in various industries like Aeronautical, Aerospace, Structural type and Automotive applications. There are several factors namely (weight percent, volume percent, particle size, aspect ratio, reinforcement orientation, reinforcement distribution, fiber spacing, and interfacial bonds) affects the thermo physical properties of MMCs and HMMCs[1]. The machining of MMCs and HMMCs on electrical discharge machining (EDM) and Wire electrical discharge machining (WEDM) have been reported by many researchers. Electrical Discharge Machining (EDM) is a process that removes metal with good dimensional control from any soft or hard metal. It cannot be used for machining glass, ceramics or other non conducting materials. The electrically conductive materials can be machined by WEDM process. The WEDM process is able to machine hard, complex, precise and irregular shapes for forging, press tools, extrusion dies, and difficult internal shapes for aerospace and medical applications can be made by WEDM process [2]. During machining through wire EDM the material removal rate (MMR) decreases and surface roughness increases with increase in wt.\% fraction of reinforcement particles in the MMCs and HMMCs[3]. The hardness of the MMC fabricated by friction stir welded process was on higher side for applied pressure [4], adding more filler content [5] and rotational speed [6]. The mechanical properties of MMC like yield stress and Young's modulus decreases with the increase in temperature during the FSW process [7]. 
It has been reported by many researcher that the machining of composite material on WEDM, the kerf width improved significantly by varying the process parameters [8\&9]. The effect of process parameters ( $\mathrm{T}_{\mathrm{on}}, \mathrm{T}_{\text {off, }}$ gap voltage, servo feed and wire feed) on MMR was carried out on MMC of $\mathrm{Al} 6063$ by WEDM. It was reported that the increase in vol. \% of SiC resulted in decreased MRR[10]. The surface roughness $\left(\mathrm{R}_{\mathrm{a}}\right)$ increases with increase in the volume fractions of $\mathrm{SiC}$ particles in the MMCs [11]. The formulated $\mathrm{Al} 6063 / \mathrm{Al}_{2} \mathrm{O}_{3}$ composite with alumina was machined on WEDM by using response surface methodology (RSM) technique. It was reported that the good surface finish and optimized MRR was achieved [9].

The effect of process parameters ( $\mathrm{T}_{\text {off }}$ and servo voltage) of WEDM during machining of MMCs $\mathrm{Al}$ 6063/ $\mathrm{ZrSiO}_{4}$ (5\%) was reported by using of Box-Behnken design approach of RSM. The cutting rate was decreased with increase in process parameters [12]. The effects of input parameters (dielectric conductivity, wire feed rate, wire mechanical tension and dielectric injection pressure) of $\mathrm{EDM}$ during machining of $\mathrm{Al} / \mathrm{ZrO}_{2}$ particle composite on MRR. The higher MRR was achieved with the increase in input parameters [13]. The investigation of input process parameter like Oxygen gas, used as dielectric fluid, in the dry WEDM process was carried out. They observed a significant effect on the cutting velocity and surface [14].

The main objective of the present study was to fabricate a MMCs \&HMMCs by varying different wt. $\%$ of reinforcement of $\mathrm{SiC}$ and $\mathrm{Al}_{2} \mathrm{O}_{3}$ through stir casting technique. The optimization technique through taguchi's method was used on various process parameters on WEDM. The demineralised water as a dielectric fluid and brass wire for the cutting process was needed to obtain the optimized values of response (cutting speed, MRR and $R_{a}$ ). The experiments were planned using Taguchi's orthogonal array methodology according to the Design Expert-9 software and an L-25 orthogonal array was selected for entire experimental work. Taguchi method was used, a special design of orthogonal arrays, to study the entire parameter space with a small number of experiments.

\section{EXPERIMENTAL SETUP}

\subsection{Material Selection}

The commercial grade aluminium alloy was purchased from M/s Ladhani Metal Corporation; Mumbai (India).The ceramic was used as reinforcement material since it provides a very desirable combination of properties like stiffness, strength and relatively low density. Figure 1 shows the Aluminium Alloy (6063), $\mathrm{Al}_{2} \mathrm{O}_{3}$ and $\mathrm{SiC}$ particles. The composition and properties $\mathrm{Al}$ alloy, reinforcements $\left(\mathrm{Al}_{2} \mathrm{O}_{3}\right.$ and $\mathrm{SiC}$ particles $)$ have been reported in the literature [14].

\subsection{Fabrication of $M M C_{S}$ and $H M M C_{S}$}

The five specimens were made by using different composition of Aluminium alloy matrix reinforced with $\mathrm{SiC}$ and $\mathrm{Al}_{2} \mathrm{O}_{3}$ particles of 400 mesh sizes. Aluminium alloy reinforced with $5 \mathrm{wt} \% \mathrm{SiC}$ and $5 \mathrm{wt} \% \mathrm{Al}_{2} \mathrm{O}_{3}$ as shown in the Table 1 . The matrix alloy was first melted in a graphite crucible in electric resistance furnace. The small ingots of Al6063 was melted in clay graphite crucible using an electric resistance furnace and $2 \mathrm{wt} . \%$ magnesium $(\mathrm{Mg})$ has been added into liquid metal, in order to achieve a strong bonding by decreasing the surface energy (wetting angle) between the matrix alloy and the reinforcement particles. The addition of pure magnesium has also enhanced the fluidity of the molten metal. The $\mathrm{SiC}$ particles and $\mathrm{Al}_{2} \mathrm{O}_{3}$ particles preheated in muffle furnace at $650^{\circ} \mathrm{C}$ for 5 hours to make the surface of $\mathrm{SiC}$ and $\mathrm{Al}_{2} \mathrm{O}_{3}$ oxidized in both case of $5 \%$ of $\mathrm{SiC}$ and $\mathrm{Al}_{2} \mathrm{O}_{3}$. The furnace temperature was raised above the liquidus temperature to melt the alloy completely at $850^{\circ} \mathrm{C}$. It was cooled down just 
below the liquidus temperature to keep the slurry in a semi solid state. At this stage, the reheated $\mathrm{SiC}$ and $\mathrm{Al}_{2} \mathrm{O}_{3}$ were added and mixed thoroughly one by one by mechanical stirrer. In case of HMMCs, before mixing of the $\mathrm{SiC}$ and $\mathrm{Al}_{2} \mathrm{O}_{3}$ particles with the liquid $\mathrm{Al} 6063$, particles was preheated at $650^{\circ} \mathrm{C}$ for 5 hours in muffle furnace. The composite slurry was reheated to a fully liquid state and then automatic mechanical mixing was done for 10 minutes by stirrer (at speed $350 \mathrm{rpm}$ ). In this experiment, the molten composite was transferred from the crucible into the mild steel mold (dimension: $160 \mathrm{~mm} \times 50 \mathrm{~mm} \times 50 \mathrm{~mm}$ ).

Table 1: Composition of composites:

\begin{tabular}{cccccc}
\hline Composition & $\begin{array}{c}\mathrm{Al} 6063 \\
(\%)\end{array}$ & $\begin{array}{c}\mathrm{Al}+\mathrm{SiC} \\
(\%)\end{array}$ & $\begin{array}{c}\mathrm{Al}+\mathrm{Al}_{2} \mathrm{O}_{3} \\
(\%)\end{array}$ & $\begin{array}{c}\mathrm{Al}+\mathrm{SiC}+\mathrm{Al}_{2} \mathrm{O}_{3} \\
(\%)\end{array}$ & $\begin{array}{c}\mathrm{Al}+\mathrm{SiC}_{2}+\mathrm{Al}_{2} \mathrm{O}_{3} \\
(\%)\end{array}$ \\
\hline $\begin{array}{c}\text { Reinforcement }(\mathrm{SiC} \\
\left.\text { and } \mathrm{Al}_{2} \mathrm{O}_{3}\right) \text { Weight } \%\end{array}$ & 0 & 5 & 5 & $3+3$ & $5+5$ \\
\hline
\end{tabular}

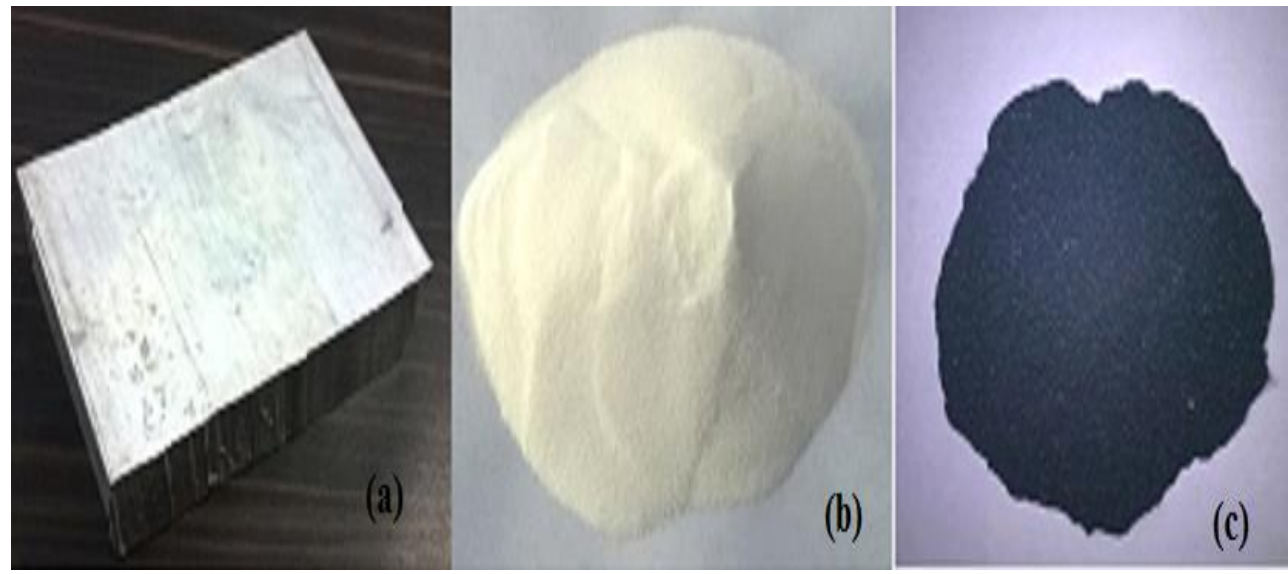

Fig. 1 The photograph images of (a) cast $\mathrm{Al} 6063$ alloy (b) $\mathrm{Al}_{2} \mathrm{O}_{3}$ Particle (c) SiC Particles

\subsection{Density and Hardness}

The theoretical density was calculated by using rule-of-mixture, the density measurements were carried out on the base alloy and reinforced samples using Archimedes principle [15]. The density of material, which is ratio of weight to volume[16] and Theoretical density, was derived from Halpin-Tsai equation. The theoretical density calculated by using formula given in the Eq. (1)

$$
\rho_{c t}=\frac{1}{\frac{W_{r}}{\rho_{r}}+\frac{W_{m}}{\rho_{m}}}
$$

Whereas, $\rho_{\mathrm{ct}=}$ theoretical density, $\mathrm{W}_{\mathrm{r}}=$ weight fraction of reinforcement, $\rho_{\mathrm{r}}=$ density of reinforcement, $\mathrm{W}_{\mathrm{m}}=$ weight fraction of matrix, $\rho_{\mathrm{m}}=$ density of matrix.

The densities of the respective specimen were calculated by measuring the mass and the volume by using the balance and the measuring cylinder respectively. The density was estimated by using formula given in the Eq. (2) [17].

$$
\rho=\frac{m}{v}
$$

The experimental and theoretical densities void fraction/ porosity was calculated by using formula as given in the Eq. (3) 


$$
V_{v}=\frac{\rho_{c t}-\rho_{c e}}{\rho_{c t}} \times 100
$$

Whereas: $\mathrm{V}_{\mathrm{v}}=$ void fraction or porosity $(\%), \rho_{\mathrm{ct}}=$ theoretical density, $\rho_{\mathrm{ce}}=$ experimental density of composites.

The hardness was measured by the computerized Vickers hardness testing machine. The specifications of the machine ASTM- E92 standards the hardness test was conducted on the samples. The brief specification of the machine is given here, Test Loads $=5,10,20,30,50$ $\mathrm{kg}, 1 \mathrm{~kg}$ optional, Magnification of optical measuring device $=10 \mathrm{X}$, Max. Test height= $230 \mathrm{~mm}$, scale least count $(\mathrm{mm})=0.001$, throat depth $(\mathrm{mm})=135$, dwell time $=0.30 \pm 2 \mathrm{sec}$ adjustable, (Model: VM50-PC). Hardness of all the samples were measured under a load of $1 \mathrm{~kg}$ and noted down. The five specimens were taken from each \%wt. of reinforcements, and the test has been conducted on various surfaces of the samples. The average hardness value was obtained for the sample.

\section{MACHINING THROUGH WEDM}

\subsection{Machine Tool, Process Parameters \& Responses}

The experiments were carried out on a wire-cut EDM machine (ECOCUT EPULSE 15) of Electronica Machine Tools Ltd, Pune, (India). There are various process variables which affect the machining characteristics of wire cut EDM. Based on the past experience of the researchers, the following process parameters have been selected (namely: Pulse on time $\left(\mathrm{T}_{\text {on }}\right)$, Pulse off Time $\left(\mathrm{T}_{\text {off }}\right.$ ), Servo reference voltage $(\mathrm{SV})$, Wire feed speed (WFS), Servo Feed (SF)). The response in terms of output parameters were cutting speed, surface roughness $\left(\mathrm{R}_{\mathrm{a}}\right)$, material removal rate (MRR). The Process parameters and their range have been presented in Table 2.

Table 2: Process parameters and Range of WEDM machine

\begin{tabular}{lcccccc}
\hline Name & Units & Type & Changes & Std. Dev. & Low & High \\
\hline Pulse On Time $\left(\mathrm{T}_{\text {on }}\right)$ & $\mu \mathrm{s}$ & Factor & Easy & 0 & 100 & 131 \\
Pulse Off Time $\left(\mathrm{T}_{\text {off }}\right)$ & $\mu \mathrm{s}$ & Factor & Easy & 0 & 0 & 63 \\
Wire Feed speed & $\mathrm{m} / \mathrm{min}$ & Factor & Easy & 0 & 1 & 15 \\
Servo Reference Voltage & volt & Factor & Easy & 0 & 0 & 99 \\
Servo Feed & $\mathrm{mm} / \mathrm{min}$ & Factor & Easy & 0 & 2000 & 3000 \\
\hline
\end{tabular}

\subsection{Optimization Technique and Design of Experiment (DOE)}

In the present work, Taguchi experimental design approach was used. It was achieved with the help of design expert-9 software. The six factors were taken as input parameters (Control factors) and five levels of each factor were considered in the experimental work. The central composite design approach of Taguchi was selected for the experiment. The experiments were planned using Taguchi's orthogonal array methodology and an L-25 orthogonal array was selected. Taguchi method uses a special design of orthogonal arrays to study the entire parameter space with a small number of experiments only. A statistical analysis of variance (ANOVA) was performed to identify the process parameters which are statistically significant. In Taguchi method, a loss function was used to calculate the deviation between the experimental value and the desired value. In WEDM, for better performance the lower value of surface roughness and kerf width was preferred. The lower-the-better criteria for surface roughness and kerf width were selected for obtaining optimum performance characteristics [18]. The experimental design according to the Design Expert -9 software is presented in Table 3 . The designs of experiment 25 runs were generated with the help of six factors and five levels. 
Table 3: Experimental design according to design expert

\begin{tabular}{|c|c|c|c|c|c|c|}
\hline \multirow{2}{*}{ Run } & Factor 1 & Factor 2 & Factor 3 & Factor 4 & Factor 5 & Factor 6 \\
\hline & A:composition & $\mathrm{B}: \mathrm{T}_{\mathrm{on}}(\mu \mathrm{s})$ & $\mathrm{C}: \mathrm{T}_{\mathrm{off}}(\mu \mathrm{s})$ & $\begin{array}{c}\mathrm{D}: \mathrm{WF} \\
(\mathrm{m} / \mathrm{min})\end{array}$ & $\begin{array}{l}\text { E:SV } \\
\text { (Volt) }\end{array}$ & $\begin{array}{c}\mathrm{F}: \mathrm{SF} \\
(\mathrm{mm} / \mathrm{min})\end{array}$ \\
\hline 1 & Pure Al & 116 & 54 & 8 & 40 & 2120 \\
\hline 2 & $\mathrm{Al}+\mathrm{Al}_{2} \mathrm{O}_{3} 5 \%$ & 118 & 50 & 8 & 50 & 2070 \\
\hline 3 & $\mathrm{Al}+\mathrm{SiC}+\mathrm{Al}_{2} \mathrm{O}_{3}(5 \%+5 \%)$ & 112 & 58 & 9 & 40 & 2070 \\
\hline 4 & $\mathrm{Al}+\mathrm{Al}_{2} \mathrm{O}_{3} 5 \%$ & 116 & 58 & 7 & 45 & 2020 \\
\hline 5 & Pure Al & 114 & 52 & 7 & 35 & 2070 \\
\hline 6 & $\mathrm{Al}+\mathrm{Sic}+\mathrm{Al}_{2} \mathrm{O}_{3}(3 \%+3 \%)$ & 120 & 54 & 6 & 45 & 2070 \\
\hline 7 & Pure Al & 118 & 56 & 9 & 45 & 2170 \\
\hline 8 & $\mathrm{Al}+\mathrm{SiC}+\mathrm{Al}_{2} \mathrm{O}_{3}(5 \%+5 \%)$ & 118 & 54 & 7 & 30 & 2220 \\
\hline 9 & $\mathrm{Al}+\mathrm{SiC} 5 \%$ & 118 & 58 & 6 & 35 & 2120 \\
\hline 10 & $\mathrm{Al}+\mathrm{SiC}+\mathrm{Al}_{2} \mathrm{O}_{3}(5 \%+5 \%)$ & 116 & 52 & 6 & 50 & 2170 \\
\hline 11 & $\mathrm{Al}+\mathrm{Sic}+\mathrm{Al}_{2} \mathrm{O}_{3}(3 \%+3 \%)$ & 118 & 52 & 10 & 40 & 2020 \\
\hline 12 & $\mathrm{Al}+\mathrm{SiC}+\mathrm{Al}_{2} \mathrm{O}_{3}(5 \%+5 \%)$ & 114 & 50 & 10 & 45 & 2120 \\
\hline 13 & $\mathrm{Al}+\mathrm{SiC} 5 \%$ & 112 & 52 & 8 & 45 & 2220 \\
\hline 14 & $\mathrm{Al}+\mathrm{Al}_{2} \mathrm{O}_{3} 5 \%$ & 112 & 54 & 10 & 35 & 2170 \\
\hline 15 & $\mathrm{Al}+\mathrm{Al}_{2} \mathrm{O}_{3} 5 \%$ & 114 & 56 & 6 & 40 & 2220 \\
\hline 16 & Pure Al & 112 & 50 & 6 & 30 & 2020 \\
\hline 17 & $\mathrm{Al}+\mathrm{SiC} 5 \%$ & 116 & 56 & 10 & 30 & 2070 \\
\hline 18 & Pure $\mathrm{Al}$ & 120 & 58 & 10 & 50 & 2220 \\
\hline 19 & $\mathrm{Al}+\mathrm{Sic}+\mathrm{Al}_{2} \mathrm{O}_{3}(3 \%+3 \%)$ & 114 & 58 & 8 & 30 & 2170 \\
\hline 20 & $\mathrm{Al}+\mathrm{Al}_{2} \mathrm{O}_{3} 5 \%$ & 120 & 52 & 9 & 30 & 2120 \\
\hline 21 & $\mathrm{Al}+\mathrm{Sic}+\mathrm{Al}_{2} \mathrm{O}_{3}(3 \%+3 \%)$ & 116 & 50 & 9 & 35 & 2220 \\
\hline 22 & $\mathrm{Al}+\mathrm{SiC} 5 \%$ & 114 & 54 & 9 & 50 & 2020 \\
\hline 23 & $\mathrm{Al}+\mathrm{Sic}+\mathrm{Al}_{2} \mathrm{O}_{3}(3 \%+3 \%)$ & 112 & 56 & 7 & 50 & 2120 \\
\hline 24 & $\mathrm{Al}+\mathrm{SiC} 5 \%$ & 120 & 50 & 7 & 40 & 2170 \\
\hline 25 & $\mathrm{Al}+\mathrm{SiC}+\mathrm{Al}_{2} \mathrm{O}_{3}(5 \%+5 \%)$ & 120 & 56 & 8 & 35 & 2020 \\
\hline
\end{tabular}

\subsection{Material Removal Rate (MRR) and Surface Roughness (Ra)}

Material removal rate was calculated by using the volume loss from the work piece in terms of cubic millimetre per minute $\left(\mathrm{mm}^{3} / \mathrm{min}\right)$. The weight loss (i.e. difference between the weight of work piece before machining and the weight of the work piece after machining) was measured by an electronic balance machine (Shinko Denshi Co. Ltd. Japan) with a least count of $0.001 \mathrm{gm}$. The MRR value was calculated by the mathematical expression [19] as given in the Eq. (4).

$$
M M R=\frac{W_{a}-W_{b}}{T_{m} \times \rho}
$$

Where $\mathrm{W}_{\mathrm{a}}$ and $\mathrm{W}_{\mathrm{b}}$ are the weight of work-piece before and after machining. $\mathrm{T}_{\mathrm{m}}$ is machining time and $\rho$ is the density. The surface roughness was measured by using surface tester (Mitutoyo Surf test SJ-201P).

\section{RESULTS AND DISCUSSION}

The microstructures of cast $\mathrm{Al} 6063$ were observed as per the ASTM E3-11 standard by using optical microscope (make: Dewinter optical, type: trinocular inverted). It was observed 
that the microstructure images of cast Al 6063 with or without etchant. There is no reinforcement added hence there is minimum porosity as compared to other compositions. The porosity due to the presence of reinforcement ( $\mathrm{SiC} 5 \mathrm{wt} \%$.). The particles have formed clusters due to non homogeneous distribution during the casting process.

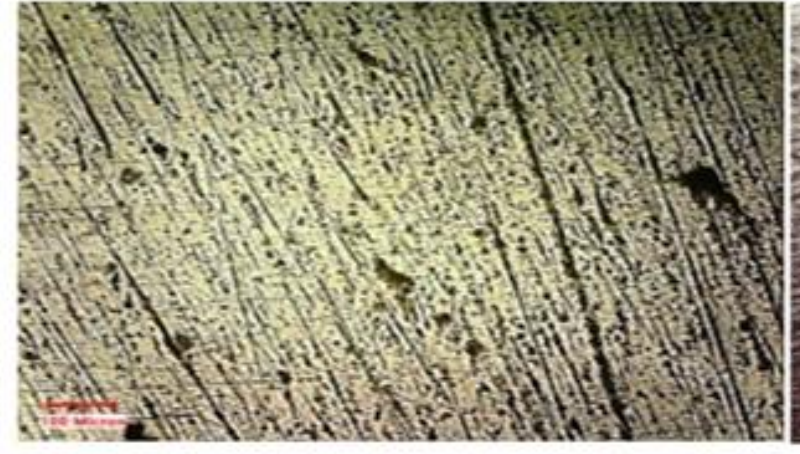

(a)

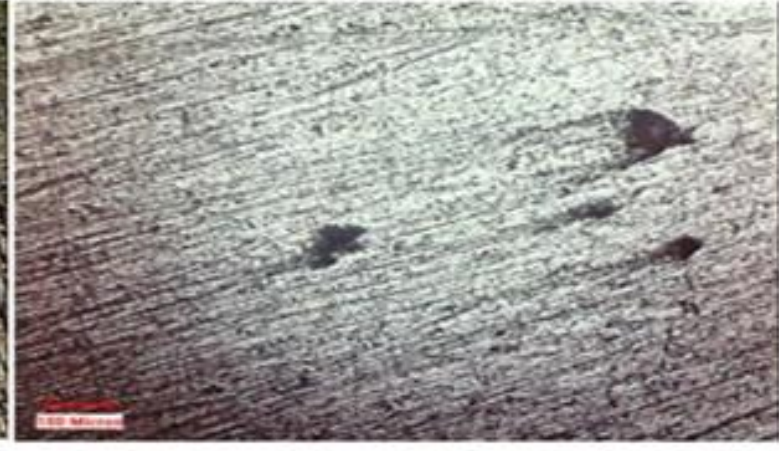

(b)

Fig. 2 Optical Microstructure of HMMC (a) image without etchant (b) image with etchant

The images of $\mathrm{HMMC}\left(\mathrm{Al}+\mathrm{SiC}\right.$ wt. $\left.3 \%+\mathrm{Al}_{2} \mathrm{O}_{3} \mathrm{wt} .3 \%\right)$ as shown in figure 2, the porosity are seen in the image due to inhomogeneous mixture of particles in matrix where particles formed cluster. The optical microstructure image of $\mathrm{HMMC}\left(\mathrm{Al}+\mathrm{SiC}\right.$ wt. $5 \%+\mathrm{Al}_{2} \mathrm{O}_{3}$ wt.5\%) which is not shown here indicates the $\mathrm{SiC}$ and $\mathrm{Al}_{2} \mathrm{O}_{3}$ reinforcement particles were added in primary matrix. Both particles form clusters and not distributed homogeneously (i.e. improper interface between matrix and reinforcement). However, the addition of reinforcement particles $\mathrm{SiC}$ wt.5\% results in agglomeration and produce cluster formation. The maximum porosity was seen during casting. The air bubbles entering the slurry either independently or as an air envelope to the reinforcement particles, the gas entrainment was observed during vigorous stirring. The evolution of hydrogen and shrinkage during solidification take place. The casting parameters may be the core reason that causes porosity formation. These parameters namely; casting route applied, stirring speed and position of the impeller, weight fraction of the reinforcement material affect the holding time. It was observed that the porosity of $\mathrm{HMMC}\left(\mathrm{Al}+\mathrm{SiC}\right.$ wt. $\left.5 \%+\mathrm{Al}_{2} \mathrm{O}_{3} \mathrm{wt} .5 \%\right)$ increases with improper dispersion of the weight $\%$ of reinforcement.

Table 4 Experiment and theoretical density \& porosity and their hardness:

\begin{tabular}{lllllllll}
\hline Composition & $\begin{array}{l}\text { Mass in } \\
(\mathrm{g})\end{array}$ & $\begin{array}{l}\text { Initial } \\
\text { volume } \\
(\mathrm{ml})\end{array}$ & $\begin{array}{l}\text { Final } \\
\text { volume }(\mathrm{ml})\end{array}$ & $\begin{array}{l}\text { Net } \\
\text { volume } \\
(\mathrm{ml})\end{array}$ & $\begin{array}{l}\text { Expt. } \\
\text { Density } \\
\left(\mathrm{g} / \mathrm{cm}^{3}\right)\end{array}$ & $\begin{array}{l}\text { Theotl } \\
\text { density } \\
\left(\mathrm{g} / \mathrm{cm}^{3}\right)\end{array}$ & $\begin{array}{l}\text { Porosit } \\
\mathrm{y}(\%)\end{array}$ & $\begin{array}{l}\text { Hardnes } \\
\mathrm{s}(\mathrm{Hv})\end{array}$ \\
\hline $\mathrm{Pure} \mathrm{Al} 6063$ & 21.464 & 70 & 78.0 & 8.0 & 2.68 & 2.70 & 0.74 & 56.0 \\
$\mathrm{Al}+\mathrm{SiC}$ wt.5\% & 20.246 & 70 & 77.5 & 7.5 & 2.69 & 2.72 & 1.10 & 65.9 \\
$\mathrm{Al}+\mathrm{Al}_{2} \mathrm{O}_{3} 5 \%$ & 21.654 & 70 & 78.0 & 8.0 & 2.70 & 2.74 & 1.45 & 61.4 \\
$\mathrm{Al}+\mathrm{SiC}\left(\right.$ wt.3\%) $+\mathrm{Al}_{2} \mathrm{O}_{3}$ (wt.3\%) & 20.987 & 70 & 77.5 & 7.5 & 2.79 & 2.84 & 1.76 & 77.5 \\
$\mathrm{Al}+\mathrm{SiC}\left(\right.$ wt.5\%) $+\mathrm{Al}_{2} \mathrm{O}_{3}$ (wt.5\%) & 19.987 & 70 & 77 & 7.0 & 2.85 & 2.87 & 2.13 & 85.8 \\
\hline
\end{tabular}

The comparison of theoretical density which was obtained by rule of mixture and experimental density values of the composites containing wt $\%$ of reinforcements has been presented in Table 4. It was found that the densities of the composites were higher than that of base alloy; the density increases with increase in the wt $\%$ of reinforcement content and porosity depend upon the homogenous mixture of reinforcement particles during casting. The hardness is an important property which affects all mechanical and tribological properties of any metal or alloy. The hardness of the composite increased with increase in the 
reinforcement. The possible reason is due to resistance to deformation by adding $\mathrm{SiC}$ and $\mathrm{Al}_{2} \mathrm{O}_{3}$ particles as given in table 5. The round specimens of $6 \times 10 \mathrm{~mm}$ were prepared and these were polished by using different grits of emery papers. Hardness was measured for the applied load $1 \mathrm{kgf}$ with diamond pyramid indenter. It was observed the hardness was increased with increase wt $\%$ of reinforcement (mesh size of $\mathrm{SiC}$ and $\mathrm{Al}_{2} \mathrm{O}_{3}$ was 400).

Table 5: Response of machining as per DOE:

\begin{tabular}{|c|c|c|c|c|c|c|c|c|c|}
\hline \multirow[t]{2}{*}{ Run } & Factor 1 & Factor 2 & Factor 3 & Factor 4 & Factor 5 & Factor 6 & $\begin{array}{l}\text { Response } \\
1\end{array}$ & Response 2 & Response 3 \\
\hline & composition & $\begin{array}{l}\text { Ton } \\
(\mu \mathrm{s})\end{array}$ & $\begin{array}{l}\text { Toff } \\
(\mu \mathrm{s})\end{array}$ & $\begin{array}{l}\text { WF } \\
(\mathrm{m} / \mathrm{min})\end{array}$ & $\begin{array}{l}\text { SV } \\
\text { (volt) }\end{array}$ & $\begin{array}{l}\mathrm{SF} \\
(\mathrm{mm} / \mathrm{min})\end{array}$ & $\begin{array}{l}\text { Cutting } \\
\text { speed } \\
(\mathrm{mm} / \mathrm{min})\end{array}$ & $\begin{array}{l}\text { MRR } \\
\left(\mathrm{mm}^{3} / \mathrm{min}\right)\end{array}$ & $\mathrm{Ra}(\mu \mathrm{m})$ \\
\hline 1 & Pure Al & 116 & 54 & 8 & 40 & 2120 & 2.83 & 18.453 & 3.14 \\
\hline 2 & $\mathrm{Al}+\mathrm{Al}_{2} \mathrm{O}_{3} 5 \%$ & 118 & 50 & 8 & 50 & 2070 & 2.39 & 14.457 & 3.11 \\
\hline 3 & $\begin{array}{l}\mathrm{Al}+\mathrm{SiC}+\mathrm{Al}_{2} \mathrm{O}_{3} \\
(5 \%+5 \%)\end{array}$ & 112 & 58 & 9 & 40 & 2070 & 1.53 & 10.522 & 2.78 \\
\hline 4 & $\mathrm{Al}+\mathrm{Al}_{2} \mathrm{O}_{3} 5 \%$ & 116 & 58 & 7 & 45 & 2020 & 1.84 & 11.857 & 3.14 \\
\hline 5 & pure $\mathrm{Al}$ & 114 & 52 & 7 & 35 & 2070 & 3.32 & 22.054 & 3.08 \\
\hline 6 & $\begin{array}{l}\mathrm{Al}+\mathrm{SiC}+\mathrm{Al}_{2} \mathrm{O}_{3} \\
(3 \%+3 \%)\end{array}$ & 120 & 54 & 6 & 45 & 2070 & 2.52 & 16.426 & 3.06 \\
\hline 7 & pure $\mathrm{Al}$ & 118 & 56 & 9 & 45 & 2170 & 3.07 & 21.69 & 3.12 \\
\hline 8 & $\begin{array}{l}\mathrm{Al}+\mathrm{SiC}+\mathrm{Al}_{2} \mathrm{O}_{3} \\
(5 \%+5 \%)\end{array}$ & 118 & 54 & 7 & 30 & 2220 & 4.21 & 18.882 & 3.27 \\
\hline 9 & $\mathrm{Al}+\mathrm{SiC} 5 \%$ & 118 & 58 & 6 & 35 & 2120 & 2.89 & 18.368 & 3.27 \\
\hline 10 & $\begin{array}{l}\mathrm{Al}+\mathrm{SiC}+\mathrm{Al}_{2} \mathrm{O}_{3} \\
(5 \%+5 \%)\end{array}$ & 116 & 52 & 6 & 50 & 2170 & 2.02 & 14.06 & 2.66 \\
\hline 11 & $\begin{array}{l}\mathrm{Al}+\mathrm{SiC}+\mathrm{Al}_{2} \mathrm{O}_{3} \\
(3 \%+3 \%)\end{array}$ & 118 & 52 & 10 & 40 & 2020 & 2.74 & 18.109 & 2.78 \\
\hline 12 & $\begin{array}{l}\mathrm{Al}+\mathrm{SiC}+\mathrm{Al}_{2} \mathrm{O}_{3} \\
(5 \%+5 \%)\end{array}$ & 114 & 50 & 10 & 45 & 2120 & 2.44 & 17.17 & 3.14 \\
\hline 13 & $\mathrm{Al}+\mathrm{SiC} 5 \%$ & 112 & 52 & 8 & 45 & 2220 & 1.9 & 12.158 & 3.06 \\
\hline 14 & $\mathrm{Al}+\mathrm{Al}_{2} \mathrm{O}_{3} 5 \%$ & 112 & 54 & 10 & 35 & 2170 & 2.26 & 15.31 & 3.16 \\
\hline 15 & $\mathrm{Al}+\mathrm{Al}_{2} \mathrm{O}_{3} 5 \%$ & 114 & 56 & 6 & 40 & 2220 & 2.13 & 14.382 & 2.8 \\
\hline 16 & pure $\mathrm{Al}$ & 112 & 50 & 6 & 30 & 2020 & 2.25 & 15.765 & 2.56 \\
\hline 17 & $\mathrm{Al}+\mathrm{SiC} 5 \%$ & 116 & 56 & 10 & 30 & 2070 & 3.15 & 20.579 & 3.14 \\
\hline 18 & pure $\mathrm{Al}$ & 120 & 58 & 10 & 50 & 2220 & 3.33 & 23.984 & 2.15 \\
\hline 19 & $\begin{array}{l}\mathrm{Al}+\mathrm{SiC}+\mathrm{Al}_{2} \mathrm{O}_{3} \\
(3 \%+3 \%)\end{array}$ & 114 & 58 & 8 & 30 & 2170 & 2.44 & 15.478 & 3.1 \\
\hline 20 & $\mathrm{Al}+\mathrm{Al}_{2} \mathrm{O}_{3} 5 \%$ & 120 & 52 & 9 & 30 & 2120 & 3.2 & 18.106 & 3.22 \\
\hline 21 & $\begin{array}{l}\mathrm{Al}+\mathrm{SiC}+\mathrm{Al}_{2} \mathrm{O}_{3} \\
(3 \%+3 \%)\end{array}$ & 116 & 50 & 9 & 35 & 2220 & 3.52 & 22.462 & 3 \\
\hline 22 & $\mathrm{Al}+\mathrm{SiC} 5 \%$ & 114 & 54 & 9 & 50 & 2020 & 1.23 & 7.952 & 2.97 \\
\hline 23 & $\begin{array}{l}\mathrm{Al}+\mathrm{SiC}+\mathrm{Al}_{2} \mathrm{O}_{3} \\
(3 \%+3 \%)\end{array}$ & 112 & 56 & 7 & 50 & 2120 & 1.02 & 15.635 & 3.06 \\
\hline 24 & $\mathrm{Al}+\mathrm{SiC} 5 \%$ & 120 & 50 & 7 & 40 & 2170 & 4.69 & 19.77 & 2.65 \\
\hline 25 & $\begin{array}{l}\mathrm{Al}+\mathrm{SiC}+\mathrm{Al}_{2} \mathrm{O}_{3} \\
(5 \%+5 \%)\end{array}$ & 120 & 56 & 8 & 35 & 2020 & 3 & 21.453 & 3.03 \\
\hline
\end{tabular}

\subsection{Response According to Experimentation}

Based on the experimental design as given above in table 5 the experiment was conducted and the values of the selected machining characteristics (cutting speed, surface roughness and material removal rate) are presented in table 5.

\subsubsection{3-D Graphs of Cutting Speed and composition Factors}

In $\mathrm{L}_{25}$ array 6 factors (Composition, $\mathrm{T}_{\text {on }}, \mathrm{T}_{\text {off, }}$, Wire Feed, Servo Voltage, Servo Feed) and 3 responses (Cutting speed, MRR and Surface roughness) have been taken and DOE has been randomly selected by the Design Expert 9 software. The effect of composition on cutting speed where $\mathrm{T}_{\text {on }}=112, \mathrm{~T}_{\text {off }}=50, \mathrm{WF}=6, \mathrm{SV}=30, \mathrm{SF}=2020$ cutting speed firstly decreases at compositon (Al+ $\mathrm{Al}_{2} \mathrm{O}_{3} \quad$ wt.5\%) then gradually increases at composition 
$\mathrm{Al}+\mathrm{SiC}(\mathrm{wt} .5 \%)+\mathrm{Al}_{2} \mathrm{O}_{3}(\mathrm{wt} .5 \%)$ due to mixinng of reinforcement of $\mathrm{SiC}(\mathrm{wt} .5 \%)+\mathrm{Al}_{2} \mathrm{O}_{3}(\mathrm{wt} .5 \%)$, and maximum at pure cast $\mathrm{Al} 6063$, as shown in figure 3 .

Design-Expert $\Theta$ Software
Factor Coding: Actual
CUTTING SPEED (mm/minute)
X1 = A: composition
X2 $=$ B: Ton
Actual Factors
C: Toff $=50$
D: WF $=6$
E: $S V=30$
F: $S F=2020$

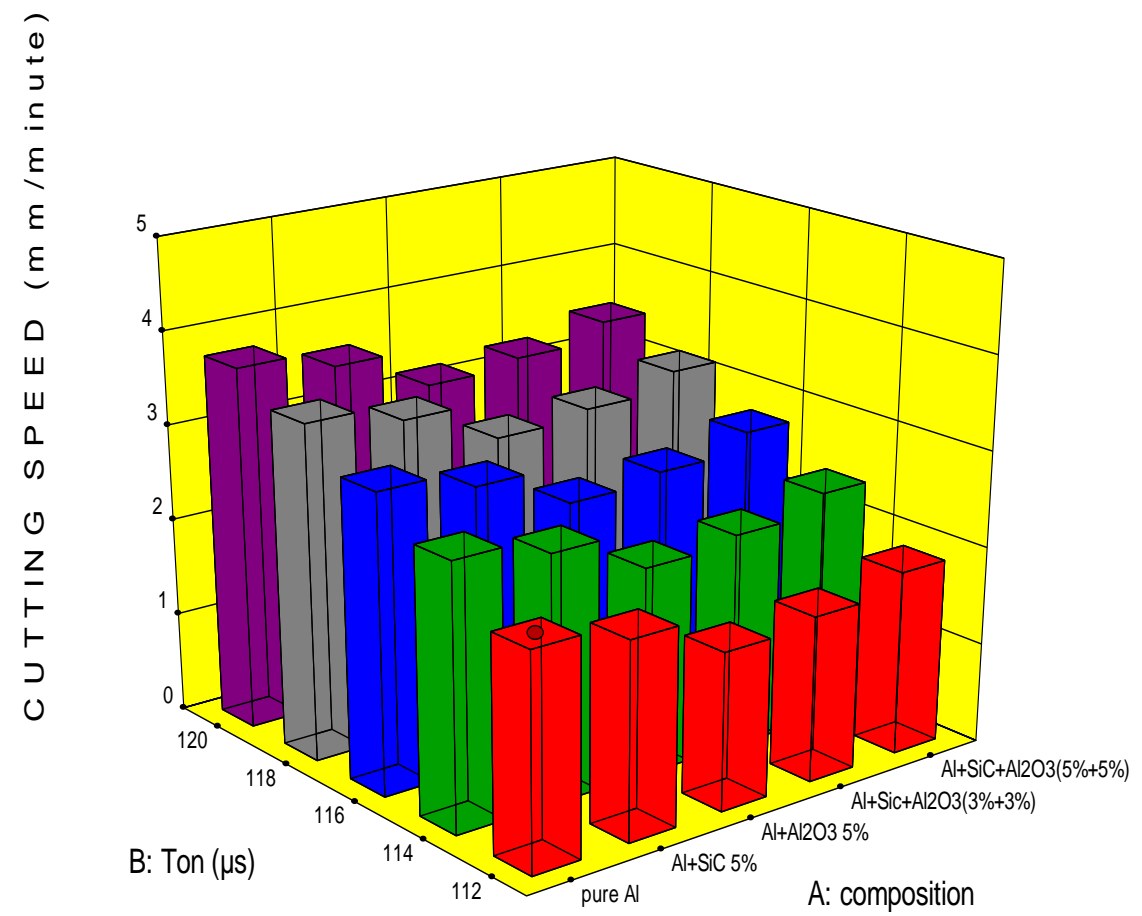

Fig. 3 Effect of composition and $\mathrm{T}_{\text {on }}$ on cutting speed

\subsubsection{3-D Graphs of MRR And composition Factors}

The effect of composition i.e. Pure cast $\mathrm{Al} 6063, \mathrm{Al}+\mathrm{SiC}$ (wt.5\%), $\mathrm{Al}+\mathrm{Al}_{2} \mathrm{O}_{3}$ (wt.5\%), $\mathrm{Al}+\mathrm{SiC}(3$ wt. $\%)+\mathrm{Al}_{2} \mathrm{O}_{3}($ wt. $3 \%)$ and $\mathrm{Al}+\mathrm{SiC}$ wt.5\%+ $\mathrm{Al}_{2} \mathrm{O}_{3}$ (wt.5\%) on material removing rate where $\mathrm{T}_{\text {on }}=112, \mathrm{~T}_{\text {off }}=50, \mathrm{WF}=6, \mathrm{SV}=30, \mathrm{SF}=2020$. The MRR value is minimum at $112 \mathrm{~T}_{\text {on }}$ with $\left(\mathrm{Al}+\mathrm{Al}_{2} \mathrm{O}_{3} 5\right.$ wt. \%), maximum at $120 \mathrm{~T}_{\text {on }}$ for pure cast $\mathrm{Al} 6063$ as shown in the figure 4 . 


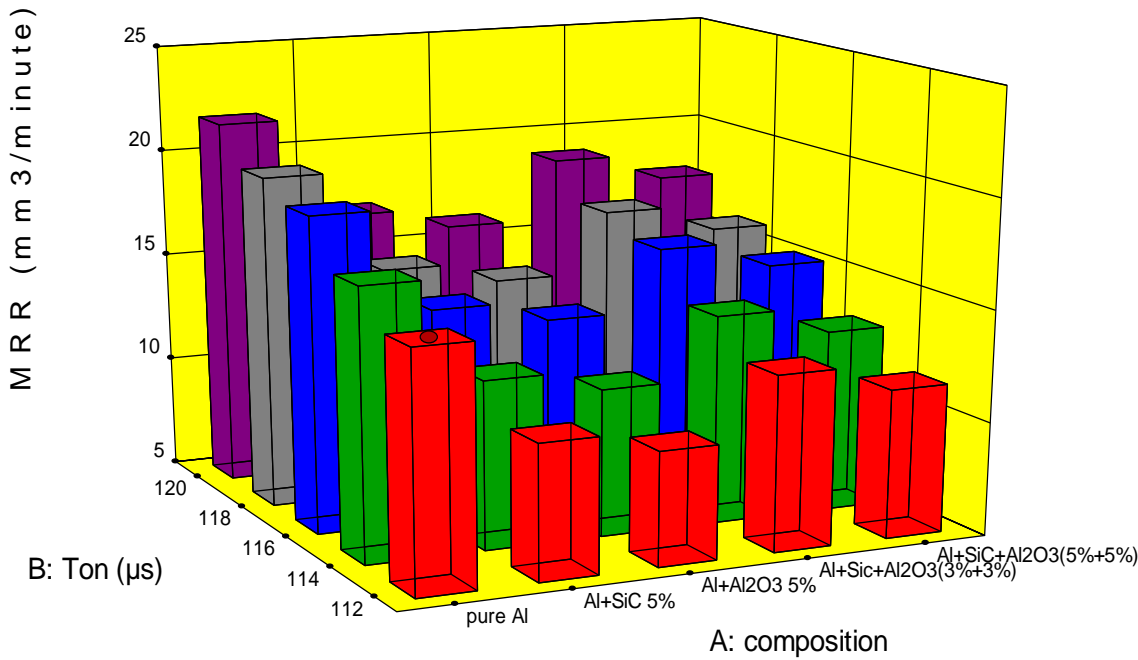

Fig. 4 Effect of composition and $\mathrm{T}_{\text {on }}$ on MRR

\subsubsection{3-D Graphs of Surface Roughness and composition Factors}

Figure 5, shows that the effect of composition i.e. Pure cast $\mathrm{Al} 6063, \mathrm{Al}+\mathrm{SiC}(5$ wt.\%), $\mathrm{Al}+\mathrm{Al}_{2} \mathrm{O}_{3}\left(5\right.$ wt.\%), $\mathrm{Al}+\mathrm{SiC}(3$ wt. $\%)+\mathrm{Al}_{2} \mathrm{O}_{3}($ wt. $3 \%)$ and $\mathrm{Al}+\mathrm{SiC}(5$ wt.\% $)+\mathrm{Al}_{2} \mathrm{O}_{3}(5$ wt. \%) on Surface roughness where $\mathrm{T}_{\text {on }}=112, \mathrm{~T}_{\text {off }}=50, \mathrm{WF}=6, \mathrm{SV}=30, \mathrm{SF}=2020$. Surface roughness increases with the composition, maximum $\mathrm{Ra}$ found on $\mathrm{Al}+\mathrm{Al}_{2} \mathrm{O}_{3}$ (wt.5\%) and minimum at pure cast Al 6063 as compared to others. 


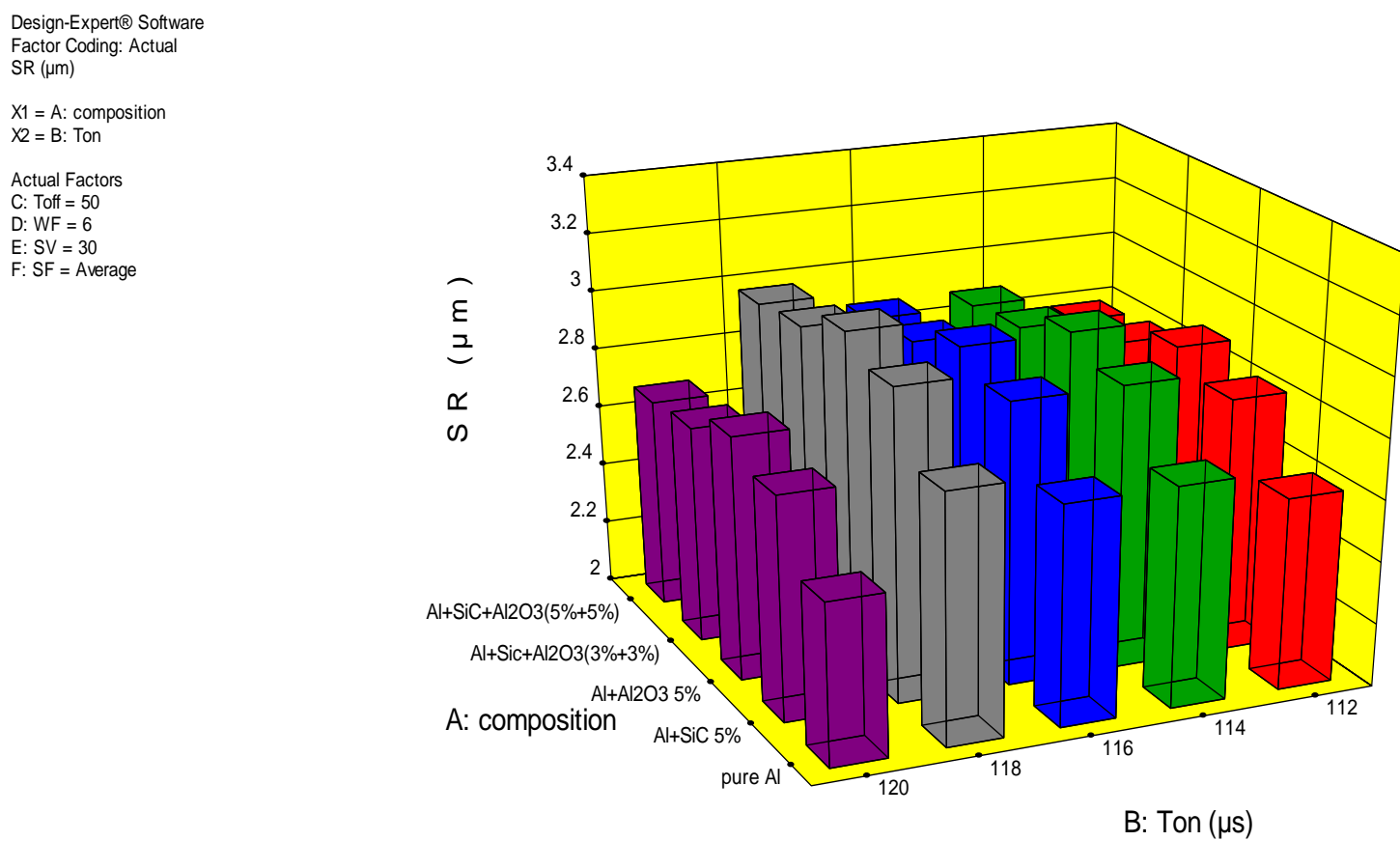

Fig. 5 Effect of composition and $\mathrm{T}_{\text {on }}$ on surface roughness

\subsubsection{Solutions for Desirability of First Ten Combinations of Category Factor Levels}

The desirability of first ten combinations of the category factor levels when MRR, cutting speed and surface roughness. The maximum desirability (0.893) was achieved for the material for composition of $\mathrm{HMMCs}\left(\mathrm{Al}+\mathrm{SiC}(5 \%)+\mathrm{Al}_{2} \mathrm{O}_{3}(5 \%)\right)$. When MRR, cutting speed are maximum and surface roughness is minimum the optimum desirability (0.986) obtained for pure Al. When cutting speed and surface roughness are minimum and MRR is maximum the optimum desirability (0.788) obtained for pure Al.

\subsection{Effect of parameters on response (cutting speed, surface roughness and material removal rate)}

The effect of individual input process parameter on cutting speed, surface roughness and material removal rate were shown in Fig.5 to Fig.7 in multi factor analysis. The graph shows the direct impact of parameter in performance measures with influence of other parameters in multiple interactions. Taguchi's experimental design was used to obtaining the machining parameters for the maximization of MRR and surface roughness. At higher values of feed rate and pulse duration increases the MRR and the surface roughness. Increase in the pulse ON time leads to the increase in both the surface roughness and the MRR and vice versa. Through ANOVA, solutions for desirability of 100 combinations of categorical factor levels were generated with the weight $\%$ of reinforcement. The optimum results shows HMMCs $\mathrm{Al}+\mathrm{SiC}+\mathrm{Al}_{2} \mathrm{O}_{3}(5 \%+5 \%)$ where minimization of cutting speed, MRR and surface roughness, in sequence of the pulse on time, pulse off time, servo voltage, wire feed, servo feed was the most significant controlled factor for the WEDM operation. The average relational factors, it was found that the smallest value of the pulse on time of $112 \mu \mathrm{s}$, the pulse OFF time of $58 \mu \mathrm{s}$. It was the recommended levels of the controllable parameters of the WEDM machining 
process as the minimization of cutting speed, surface roughness and MRR are simultaneously considered.

\section{CONCLUSIONS}

In the present work, experiments were conducted on MMCs and HMMCs for optimizing MRR, cutting speed, Surface finish. The multi objective Taguchi optimization technique theory was used in study. The stir casting technique was found to be suitable process for fabrication of MMCs and HMMCs. The hardness and density of MMCs and HMMCs were influenced by the weight percentage of reinforcement. The MRR was decreased with increase in the weight percentage of reinforcement $\left(\mathrm{SiC}\right.$ and $\left.\mathrm{Al}_{2} \mathrm{O}_{3}\right)$ particles added into the MMCs and HMMCs. The surface roughness was increased with increase in the weight percentage of reinforcement particles in the MMCs and HMMCs. MRR and wire wear rate increased with increase in pulse on time where as surface finish was decreased on increase in pulse on time. The cutting speed was increased with decrease in the pulse off time the possible reason is to allow more productive discharges per unit time. At higher value of servo voltage (SV) the gap between work piece and wire becomes wider which results in reduction of number of sparks. Whereas at smaller value of servo voltage, the mean gap becomes narrow which leads to an increase in number of electric sparks, the speed up of the machining rate and unstable discharge, results in frequent wire breakage.

\section{Acknowledgement}

The authors would like to extend sincere thanks to the Technical Education Quality Improvement Programme (TEQIP) of the college for providing full financial support to carry out the tests on the samples.

\section{References}

[1] N. Chawla, Y.N. Shen. Mechanical Behaviour of Particle Reinforced Metal Matrix Composites, Adv Eng Mater 2001 (3), 357 - 370

[2] K.H. Newman, S.T. Rahimifard, S. Allen. State of art in wire electrical discharge machining, International. Int J Mach Tool Manu, 2004 (44), 1247 - 1259.

[3] H.P. Raturi, M. Pokhriyal, L. Prasad. Parametric effects on metal matrix composite and hybrid metal matrix composite machining through WEDM -a review, $1^{\text {st }}$ national conference on "recent advance in science and technology", August 22-23, 2015; SIT, Pithoragarh, Uttarakhand (INDIA), ISBN: 978-93-85437-03-8

[4] A. Handa, V. Chawla. Experimental evaluation of mechanical properties of friction welded dissimilar steels under varying axial pressures, Journal of Mechanical Engineering - Strojnicky časopis, 2016 (66), No. 1, 27 - 36.

[5] V. K. Patel, K. Rani. Mechanical and Wear Properties of Friction Stir Welded 0-6wt\% $\mathrm{nAl}_{2} \mathrm{O}_{3}$ Reinforced Al-13wt\% Si Composites, Journal of Mechanical Engineering Strojnícky časopis, 2017 (67), No. 1, 77 - 86

[6] D. Santha Rao, N. Ramanaiah. Process Parameters Optimization for Producing AA6061/TiB2 Composites by Friction Stir Processing, Journal of Mechanical Engineering - Strojnícky časopis, 2017 (67), No. 1, 101 - 118

[7] R. Jančo, L. Écsi, P. Élesztős. FSW Numerical Simulation of Aluminium Plates by Sysweld - Part II, Journal of Mechanical Engineering - Strojnícky časopis, 2016 (66), No. 2, 29 - 36 
[8] S. Lal, S. Kumar, Z.A. Khan, A.N. Siddiquee. Wire electrical discharge machining of AA7075/SiC/ $/ \mathrm{Al}_{2} \mathrm{O}_{3}$ hybrid composite fabricated by inert gas-assisted electromagnetic stir casting process. J Braz Soc Mech Sci Eng 2014 (36), 335 - 346.

[9] K. Hemalatha, V.S.K. Venkatachalapathy, N. Alagumurthy. Surface Integrity analysis in Wire-Cut Electric Discharge Machining of $\mathrm{Al} 6063 / \mathrm{Al}_{2} \mathrm{O}_{3}$ Metal Matrix Composite through Response Surface Methodology. Applied Mechanics and Materials 2014 (592594), 534 - 539.

[10] D. Satishkumar, M. Kanthababu, V. Vajjiravelu, R. Anburaj, N.T. Sundarrajan, H. Arul. Investigation of wire electrical discharge machining characteristics of Al6063/SiCp composites. Int J Adv Manuf Technol 2011 (56), 975 - 986.

[11] K.L. Meena, A. Manna, S.S. Banwati, Jaswanti. Effect of wire feed rate and wire tension during machining of pr-Al-SiC-MMCs by WEDM, European Journal of Engineering and Technology 2013 (1), 1 - 13.

[12] A. Sharma, M.P. Garg, K.K. Goyal, Prediction of optimal conditions for WEDM of Al 6063/ ZrSiO4 (p) MMC. Procedia Materials Science 2014 (6), 1024 - 1033.

[13] S.K. Garg, A. Manna, A. Jain. An Experimental Investigation for Optimization of WEDM Parameters during Machining of Fabricated Al/ZrO 2 (p)-MMC. Arab J Sci Eng, 2013 (38), 3471 - 3483.

[14] R.K. Fard, R.A. Afza, R. Teimouri. Experimental investigation, intelligent modelling and multi-characteristics optimization of dry WEDM process of $\mathrm{Al}-\mathrm{SiC}$ metal matrix composite, Manuf Process 2013 (15), 483 - 494.

[15] M. Ramachandra, K. Radhakrishna. Sliding wear, slurry erosive wear, and corrosive wear of aluminium/SiC composite. J Mater Sci 2006 (24), 333 - 348.

[16] M.D. Bermudeza, G.M. Niccolas, F.J. Carrion, I.M. Mateoa, J.A. Rodríguez, E.J. Herrera. Dry and lubricated wear resistance of mechanically-alloyed aluminium-base sintered composites. J Wear 2001 (248), No. 1-2, 178 - 186.

[17] V.S. Aigbodin, S.B. Hassan. Effects of Silicon carbide reinforcement on Microstructure and properties of cast $\mathrm{Al}-\mathrm{Si}-\mathrm{Fe} / \mathrm{SiC}$ particulate composites. J Mater Sci Eng 2007 (447), 355 - 360.

[18] E.B. Dean, R. Unal, Taguchi approach to design optimization for quality and cost: An overview. NASA Technical Report. NASA Langley Research Centre; Hampton, VA, United States. 1990.

[19] D. Ghodsiyeh, A. Golshan, J.A. Shirvanehdeh. Review on Current Research Trends in Wire Electrical Discharge Machining. Indian J Sci Techno 2013, 4128 - 4140. 